\title{
EFEKTIFITAS ANTI INFLAMASI FORMULASI KUNYIT (CURCUMA LONGA), DAUN BINAHONG (ANREDERA CORDIFOLIA) DAN DAUN SAMBILOTO (ANDROGRAPHIS PANICULATA) TERHADAP LUKA SAYAT PADA KELINCI
}

\author{
Kh Endah Widhi Astuti, Sih Rini Handajani \\ Poltekkes Kemenkes Surakarta Jurusan Kebidanan
}

\begin{abstract}
Background: Perineal lacerations are tears that occur in the perineum because of the second stage of labor. The Javanese people do the purpose of this study is the effectiveness of anti-inflammatory formulation of turmeric (curcuma longa), leaves of Binahong (Anredera cordifolia) and leaves of Sambiloto (Andrographis paniculata) against incisions in rabbits. Method: The method used in this study is the method in this study. This research uses a quantitative method with a type of pure treatment research in the form of pre-post test design. The sample in this study was 10 rabbits per group in 5 groups. Results: There was an anti-inflammatory effect of the turmeric formulation, binahong leaves of bitter leaf (F1, F2 and F3) in the incision wound in rabbits ( $\rho$ $<0.001)$. There is an anti-inflammatory effect of turmeric formulation, binahong leaves of bitter leaf on leukocyte levels in rabbit incisions in F1, F2 and F3 compared to the control group ( $\rho<0.001)$. Conclusion: Turmeric formula, binahong leaf, bitter leaf ( $F 1$, $F 2$ and F3) in the incision in rabbits can improve the wound healing process.
\end{abstract}

Keywords: Binahong Leaves, Sambiloto Leaves, Wounds, Turmeric

\section{PENDAHULUAN}

Luka adalah peristiwa yang tidak dapat dihindari dari kehidupan yang diwujudkan sebagai hilangnya atau terputusnya seluler, anatomi, integritas, fungsional dan jaringan hidup (Bhat et al., 2007). Faktor yang menyebabkan luka seperti trauma, tergores benda tajam, sengatan hewan sampai terjadinya ledakan. Proses penyembuhan luka yang terorganisir dengan baik secara biokimiawi yaitu yang mengarah ke pertumbuhan dan regenerasi dari jaringan yang terluka secara khusus. Penyembuhan luka melibatkan aktivitas jaringan yang rumit dari sel darah, sitokin dan faktor pertumbuhan lainnya yang akhirnya mengarah ke pemulihan ke kondisi normal (Clark, 1993). Dalamnya luka akan mempengaruhi kerusakan atau gangguan integritas kulit dan kematian sel-sel ( Judd, 2007 : 13)

Keadaan luka dapat terjadi pada semua mahluk hidup. Begitu juga pada saat wanita melahirkan kemungkinan mengalami masalah ketika proses persalinan berlangsung diantaranya adalah terjadinya robekan (rupture) pada jalan lahir atau rupture pada perimeun ( Miles, 2009).Trauma perineum didefinisikan sebagai perlukaan yang terjadi pada labia, vagina, uretra, klitoris, otot perineum atau sfingter ani. Robekan ini dapat terjadi secara spontan pada saat persalinan pervaginam, atau karena tindakan bedah yang berlangsung pada saat proses persalinan Laserasi perineum merupakan robekan yang terjadi pada perineum 
karena kala II persalinan. Lebih dari $85 \%$ persalinan pervaginam akan mengalami trauma perineum, dan hampir 69\% memerlukan penjahitan (Miles, 2009). Angka kejadiannya berbeda-beda, tergantung pada praktik individu dan episiotomi yang bertujuan memperbesar vaginal outlet dan membantu fasilitas kesehatan yang ada.Empat puluh empat persen laserasi perineum terjadi karena persalinan spontan maupun buatan.Saat ini obat obat secara medis banyak di berikan untuk. mengembalikan keadaan luka perenium agar kembali normal. Budaya dari suku jawa dalam pemanfaatan tanaman di sekitar rumah sudah terjadi sejak jaman nenek moyang namun baru sedikit di buktikan secara ilmiah didiantaranya kunyit, daun binahong serta daun sambiloto yang sebenarnya mempunyai kandungan antiinflamasi dan sebagai antiseptik. Untuk itu perlu dibuktikan secara ilmiah agar pemanfaatan tanaman ini semakin nyata pemanfaatanya maka perlu pengaplikasiakn pada hewan kelinci sebelum di terapkan pada luka perenium ibu postpartum.

Kunyit (Curcuma domestica val) merupakan salah satu tanaman yang digunakan untuk pengobatan tradisional berupa semak dan bersifat tahunan yang tersebar di daerah tropis dan sub tropis.Berdasarkan hasil penelitian yang dilakukan oleh Hidayati, E (2002) secara in vitro, membuktikan bahwa senyawa aktif dalam rimpang kunyit mampu menghambat pertumbuhan jamur, virus, dan bakteri baik Gram positif maupun Gram negatif, seperti E.coli dan Staphylococcus aureus, karena kunyit mengandung berbagai senyawa diantaranya adalah kurkumin dan minyak atsiri (Said, 2001). Senyawa sesquiterpen dalam minyak atsiri Senyawa sesquiterpen dalam minyak atsiri kunyit merupakan turunan dari senyawa terpen seperti alkohol yang bersifat bakterisida dengan merusak struktur tersier protein bakteri atau denaturasi protein (Tarwiyah, 2001). Sedangkan kurkumin adalah suatu senyawa fenolik. Turunan fenol ini akan berinteraksi dengan dinding sel bakteri, selanjutnya terabsorbsi dan penetrasi ke dalam sel bakteri, sehingga menyebabkan presipitasi dan denaturasi protein, akibatnya akan melisiskan membran sel bakteri. sedangkan aktivitas antibakteri curcumin dengan cara menghambat proliferasi sel bakteri.

Tanaman yang sering di gunakan untuk pengobatan luka adalah binahong. Dalam pengobatan bagian dari tanaman binahong yang digunakan dapat berasal dari akar, batang, daun, dan bunga maupun umbi yang menempel pada ketiak daun. Tanaman ini dikenal dengan sebutan Madeira Vine dipercaya memiliki kandungan antioksidan tinggi dan antivirus. Tanaman ini masih diteliti meski dalam lingkup terbatas. Percobaan pada tikus yang disuntik dengan bahan ekstrak dari binahong dapat meningkatkan daya tahan tubuh, peningkatan agresivitas tikus dan tidak mudah sakit. Beberapa Beberapa penyakit yang dapat disembuhkan dengan menggunakan tanaman ini adalah: kerusakan ginjal, diabetes, pembengkakan jantung, muntah darah, tifus, stroke wasir, rhematik, pemulihan pasca operasi, pemulihan pasca melahirkan, menyembuhkan segala luka dalam dan khitanan, radang usus, melancarkan dan menormalkan peredaran dan tekanan darah, sembelit, sesak napas, sariawan berat, pusing-pusing, sakit perut, menurunkan panas tinggi, menyuburkan kandungan, maag, asam urat, keputihan, 
pembengkakan hati, meningkatkan vitalitas dan daya tahan tubuh (Manoi, 2009).

Menurut Tshikalange (2005). ekstrak air akar binahong dengan dosis 50 $\mathrm{mg} / \mathrm{ml}$ memiliki daya hambat terhadap bakteri gram-positif (B. pumilus, B.subtilis dan S.aureus) serta pada bakteri gram-negatif (Enterobacter cloacae, E.coli, Klebsiella pneumonia, Serratia marcescens, dan Enterobacter aerogenes) pada dosis $60 \mathrm{mg} / \mathrm{ml}$, tetapi tidak pada bakteri B.sereus. Rachmawati (2007) telah melakukan skrining fitokimia daun binahong (Anredera Cordifolia (Ten.) Steenis) dengan melakukan maserasi terhadap serbuk kering daun dengan menggunakan pelarut n-heksana danetanol didapatkan kandungan kimia berupa saponin triterpenoid, flavanoiod dan minyak atsiri. Rochani (2009) melakukan ekstraksi dengan cara maserasi daun binahong dengan menggunakan pelarut petroleum eter, etil asetat dan etanol setelah dilakukan uji tabung ditemukan kandungan alkaloid, saponin dan flavanoid, sedangkan pada analisisa kromatografi lapis tipis ditemukan senyawa alkaloid, saponin dan flavonoid. Setiaji (2009) telah melakukan ekstraksi pada rhizome binahong dengan pelarut etil asetat, petroleum eter, dan etanol $70 \%$ di dapatkan senyawa alkaloid, saponin, flavonoid dan polifenol. Pada ekstrak dengan pelarut etil asetat pada konsentrasi $2 \%$ dapat membunuh bakteri Staphylococcus aureus. Selain itu juga dijelaskan Uchida (2003) bahwa di dalam daun binahong terdapat aktifitas antioksidan, asam askorbat dan total fenol yang cukup tinggi.

Salep merupakan sediaan semi padat yang mudah dioleskan yang di dalamnya terkandung berbagai zat kimia dan berbagai obat, yang umumnya digunakan secara topikal pada bagian tubuh kulit yang mengalami gangguan, seperti luka, pegal-pegal maupun gatalgatal (Anief, 2005). Basis salep yang digunakan adalah basis salep serap (adeps lanae) yang bersifat hidrofil yang dapat menyerap kelebihan air.Selain itu pemakaian pada kulit dapat merupakan lapisan penutup, melunakkan kulit hingga salep dapat dengan mudah untuk dipakai (Anief, 1993).Maka dari itu perlu dilakukan penelitian untuk mengetahui aktivitas ketiga ramuan dari kunyit, daun binahong dan daun sambiloto ( KUBISA) yang dibuat dalam sediaan salep sebagai penyembuh luka terbuka pada kelinci sebelum di aplikasikan pada luka pereneum ibu postpartum. Sampai saat ini belum ada penelitian tentang formulasi dari ketiga bahan diantaranya kunyit, daun binahong dan daun sambiloto, sehingga peneliti tertarik dengan melakukan penelitian dengan judul "Efektifitas Anti Inflamasi Formulasi Kunyit (curcuma longa ), Daun Binahong (Anredera cordifolia) dan Daun Sambiloto (Andrographis paniculata) Terhadap Luka sayat pada kelinci"

\section{METODE PENELITIAN}

Untuk membuktikan pengaruh anti inflamasi Efektifitas Anti Inflamasi Formulasi Kunyit (curcuma longa ), Daun Binahong (Anredera cordifolia) dan Daun Sambiloto (Andrographis paniculata) Terhadap Luka luka derajat 2 pada kelinci maka jenis penelitian yang digunakan adalah uji pra klinis ( pra clinical trial) pada kelinci. Pada uji klinis peneliti memberikan perlakuan atau intervensi kepada kelinci dengan umur dan jenis yang sama dengan memberika salep dari ekstrak KUBISA 2 x sehari 
setiap pagi dan sore selama 10 hari berturut turut dan diamati setiap harinya mulai hari ke 0 sampai hari ke 10dan akan di lihat perubahan tentang keadaan luka pada kelinci tersebut

\begin{tabular}{|c|c|c|c|}
\hline \multirow{9}{*}{$\begin{array}{l}\text { Kelompok } \\
\text { Perlakuan I } \\
\text { Kelompok } \\
\text { Perlakuan II } \\
\text { Kelompok } \\
\text { Perlakuan III } \\
\text { Kelompok } \\
\text { kontrol 1 } \\
\text { Kelompok } \\
\text { Kontrol II }\end{array}$} & Pre & $\begin{array}{c}\text { Perlaku } \\
\text { an }\end{array}$ & Post \\
\hline & $\mathrm{P} 1$ & F1 & P2 \\
\hline & & & \\
\hline & $\mathrm{P} 1$ & $\mathrm{~F} 2$ & $\mathrm{P} 2$ \\
\hline & & & \\
\hline & $\mathrm{P} 1$ & F3 & $\mathrm{P} 2$ \\
\hline & & & \\
\hline & PI & $\begin{array}{l}\text { Povido } \\
\text { ne }\end{array}$ & \\
\hline & Q1 & - & Q2 \\
\hline
\end{tabular}
adalah pada Bulan Februari 2018 s.d. Juli 2018. Penelitian ini dilakukan di laboratorium Farmasi Universitas Gadjah Mada Jogjakarta.

Populasi dalam penelitian ini adalah terdiri dari 10 ekor kelinci yang usia dan berat badan sama pada setiap kelompok

Sebagai sampel dalam penelitian ini adalah 10 kelinci betina setiap kelompok dengan total 5 kelompok dengan teknik samplingnya adalah purposive sampling dengan kriteria: dimana untuk penyiapan hewan coba Kelinci diadaptasikan selama 2 minggu dalam kondisi ruangan laboratorium dengan tetap diberi makanan dan minuman. Kelinci yang digunakan adalah kelinci betina (Oryctolagus cuniculus) sehat dan memiliki berat badan antara 1,5 sampai $2 \mathrm{~kg}$.

Variabel yang diamati dalam penelitian ini terbagi dalam dua jenis yaitu : variabel bebas (independent variable) dan variabel terikat (dependent variable). Variabel bebas dalam penelitian ini adalah pemberian salep KUBISA, variabel terikatnya yaitu proses penyembuhan luka

\section{HASIL PENELITIAN}

Tabel 1. Rata-Rata Skor REEDA dan

Kadar Leukosit Pada Setiap Kelompok

\begin{tabular}{|c|c|c|c|c|}
\hline Keterangan & Mean & $\begin{array}{l}\text { Standar } \\
\text { Error }\end{array}$ & $95 \mathrm{CI} \%$ & \\
\hline Formula 1 & & & Lower & Upper \\
\hline Hari 1 & 5,8 & 0,359 & 4,988 & 6,612 \\
\hline Hari 3 & 3,8 & 0,200 & 3,348 & 4,252 \\
\hline Hari 5 & 2,0 & 0,211 & 1,523 & 2,477 \\
\hline Hari 7 & 1,3 & 0,153 & 0,954 & 1,646 \\
\hline Hari 10 & 0,0 & 0,000 & 0,000 & 0,000 \\
\hline \multicolumn{5}{|l|}{ Formula 2} \\
\hline Hari 1 & 6,2 & 0,359 & 5,388 & 7,012 \\
\hline Hari 3 & 3,6 & 0,371 & 2,760 & 4,440 \\
\hline Hari 5 & 2,5 & 0,373 & 1,657 & 3,343 \\
\hline Hari 7 & 1,3 & 0,213 & 0,817 & 1,783 \\
\hline Hari 10 & 0,0 & 0,000 & 0,000 & 0,000 \\
\hline \multicolumn{5}{|l|}{ Formula 3} \\
\hline Hari 1 & 5,1 & 0,348 & 4,313 & 5,887 \\
\hline Hari 3 & 3,2 & 0,249 & 2,636 & 3,764 \\
\hline Hari 5 & 0,6 & 0,267 & $-0,003$ & 1,203 \\
\hline Hari 7 & 4,9 & 0,314 & 4,189 & 5,611 \\
\hline Hari 10 & 0,0 & 0,000 & 0,000 & 0,000 \\
\hline \multicolumn{5}{|l|}{ Kontrol 1} \\
\hline Hari 1 & 6,2 & 0,133 & 5,898 & 6,502 \\
\hline Hari 3 & 4,3 & 0,260 & 3,711 & 4,889 \\
\hline Hari 5 & 4,3 & 0,260 & 3,711 & 4,889 \\
\hline Hari 7 & 2,5 & 0,269 & 1,892 & 3,108 \\
\hline Hari 10 & 0,9 & 0,277 & 0,274 & 1,526 \\
\hline \multicolumn{5}{|l|}{ Kontrol 2} \\
\hline Hari 1 & 7,0 & 0,365 & 6,174 & 7,82 \\
\hline Hari 3 & 5,8 & 0,291 & 5,143 & 6,45 \\
\hline Hari 5 & 5,8 & 0,533 & 4,594 & 7,006 \\
\hline Hari 7 & 5,1 & 0,567 & 3,818 & 6,382 \\
\hline Hari 10 & 2,8 & 0,512 & 1,642 & 3,958 \\
\hline
\end{tabular}

Berdasarkan tabel 1 dijelaskan

nilai rata-rata skor REEDA pada formula 1, formula 2 formula 3, Kontrol 1 dan kontrol 2. Pada formula 1 didapatkan skor REEDA hari pertama 5,8 kemudian menurun menjadi 0,0 pada hari ke sepuluh. Pada formula 2 didapatkan skor REEDA hari pertama 6,2 kemudian menurun menjadi 0,0 pada hari ke sepuluh. Pada formula 3 didapatkan skor hari pertama 5,1 kemudian menurun 
menjadi 0,0 pada hari ke sepuluh. Pada kontrol 1 (iodine) didapatkan skor hari pertama 6,2 kemudian menurun menjadi 0,9 pada hari ke sepuluh. Pada kontrol 2 didapatkan skor hari pertama 7,0 kemudian menurun menjadi 2,8 pada hari ke sepuluh.

Tabel 2. Efek anti inflamasi formulasi kunyit, daun binahong daun sambiloto (F1) pada luka sayat pada kelinci

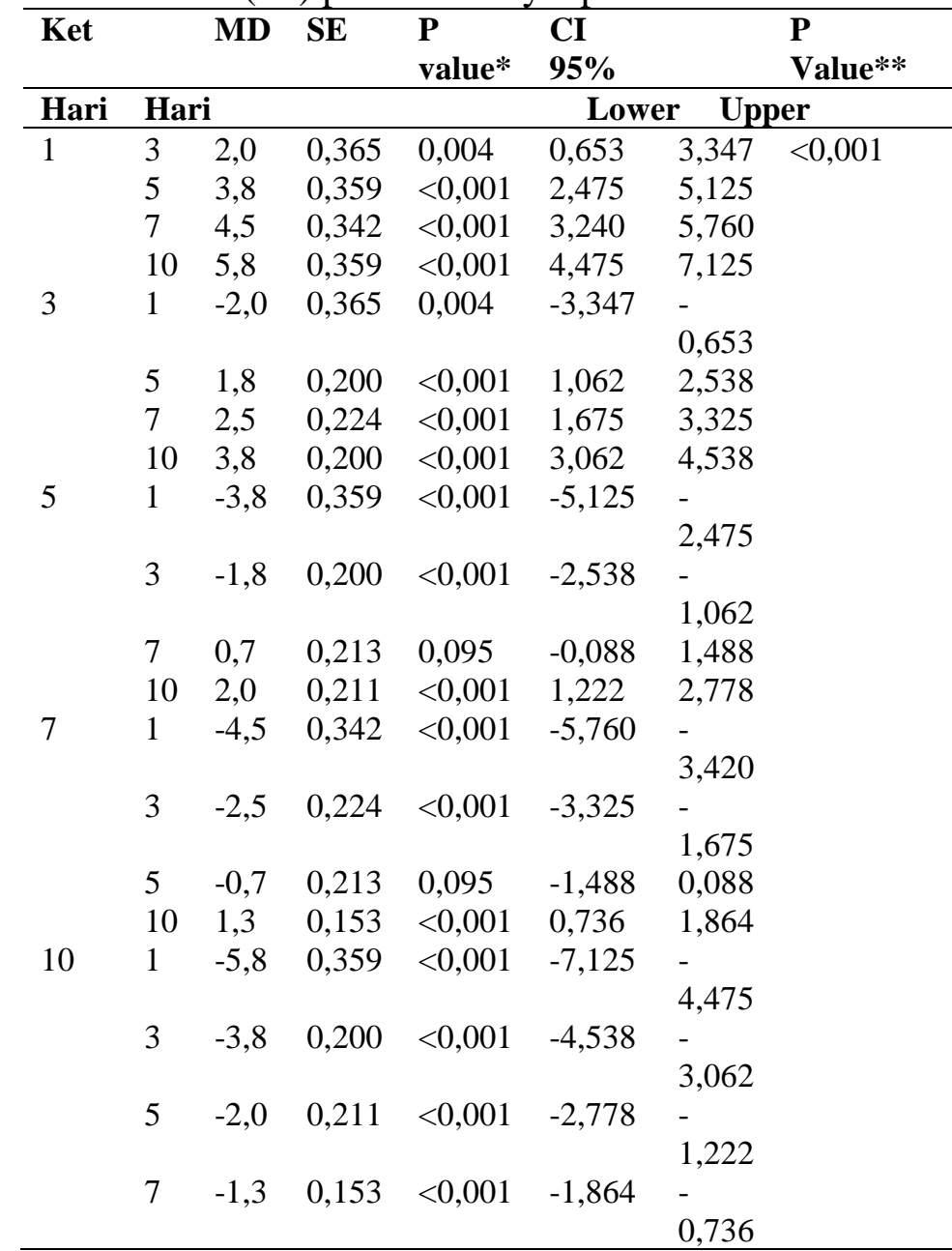

Keterangan uji : *) Bonferonni Test, **) Repeated Anova dengan koreksi Greendhouse-Geisser

Pada tabel 2 dijelakan tentang efek formula 1 terhadap penyembuhan luka. Hasil uji statistik menggunakan repeated
Anova didapatkan $p$ value $<0,001$ yang berarti bahwa terdapat pengaruh Efek anti inflamasi formulasi kunyit, daun binahong daun sambiloto( F1) pada luka sayat pada kelinci. Hasil uji ini kemudian dilanjutkan dengan uji bonferoni test untuk melihat kelompok manasajakah yang terdapat perbedaan. Hasil yang didapat adalah terdapat penurunan signifikan dalam setiap hari pemeriksaan mulai dari hari ke 1 sampai hari ke 10 ( $p$ value $<0,05)$.

Tabel 3. Efek anti inflamasi formulasi kunyit, daun binahong daun sambiloto ( F2 ) pada luka sayat pada kelinci

\begin{tabular}{|c|c|c|c|c|c|c|c|}
\hline \multicolumn{2}{|c|}{ Ket } & \multirow[t]{2}{*}{ MD } & \multirow[t]{2}{*}{ SE } & \multirow[t]{2}{*}{$\begin{array}{l}\mathbf{P} \\
\text { valu } \\
\mathrm{e}^{*}\end{array}$} & \multicolumn{2}{|l|}{$\begin{array}{l}\text { CI } \\
95 \%\end{array}$} & \multirow[t]{2}{*}{$\begin{array}{l}\mathbf{P} \\
\text { Value } \\
* *\end{array}$} \\
\hline $\begin{array}{l}\mathbf{H} \\
\text { ari }\end{array}$ & Hari & & & & $\begin{array}{l}\text { Low } \\
\text { er }\end{array}$ & $\begin{array}{l}\text { Upp } \\
\text { er }\end{array}$ & \\
\hline \multirow[t]{8}{*}{1} & 3 & 2,6 & 0,56 & 0,01 & 0,52 & 4,67 & $<0,001$ \\
\hline & & & 2 & 2 & 7 & 3 & \\
\hline & 5 & 3,7 & 0,51 & 0,00 & 1,79 & 5,60 & \\
\hline & & & 7 & 1 & 1 & 9 & \\
\hline & 7 & 4,9 & 0,43 & $<0,0$ & 3,30 & 6,49 & \\
\hline & & & 3 & 01 & 1 & 9 & \\
\hline & 10 & 6,2 & 0,35 & $<0,0$ & 4,87 & 7,52 & \\
\hline & & & 9 & 01 & 5 & 5 & \\
\hline \multirow[t]{8}{*}{3} & 1 & $-2,6$ & 0,56 & 0,01 & . & - & \\
\hline & & & 2 & 2 & $\begin{array}{l}4,67 \\
3\end{array}$ & 5,27 & \\
\hline & 5 & 1,2 & 0,37 & 0,17 & . & 2,49 & \\
\hline & & & 9 & 4 & $\begin{array}{l}0,29 \\
7\end{array}$ & 7 & \\
\hline & 7 & 2,3 & 0,47 & 0,00 & 0,55 & 4,04 & \\
\hline & & & 3 & 9 & 6 & 4 & \\
\hline & 10 & 3,6 & 0,37 & $<0,0$ & 2,23 & 4,97 & \\
\hline & & & 1 & 01 & 0 & 0 & \\
\hline \multirow[t]{9}{*}{5} & 1 & $-3,7$ & 0,51 & 0,00 & - & - & \\
\hline & & & 7 & 1 & 5609 & 1,79 & \\
\hline & & & & & & 1 & \\
\hline & 3 & $-1,1$ & 0,37 & 0,17 & - & 0,29 & \\
\hline & & & 9 & 4 & $\begin{array}{l}2,49 \\
7\end{array}$ & 7 & \\
\hline & 7 & 1,2 & 0,38 & 0,13 & - & 2,63 & \\
\hline & & & 9 & 0 & $\begin{array}{l}0,23 \\
4\end{array}$ & 4 & \\
\hline & 10 & 2,5 & 0,37 & 0,00 & 1,12 & 3,87 & \\
\hline & & & 3 & 1 & 5 & 5 & \\
\hline 7 & 1 & $-4,9$ & 0,43 & $<0,0$ & - & - & \\
\hline
\end{tabular}




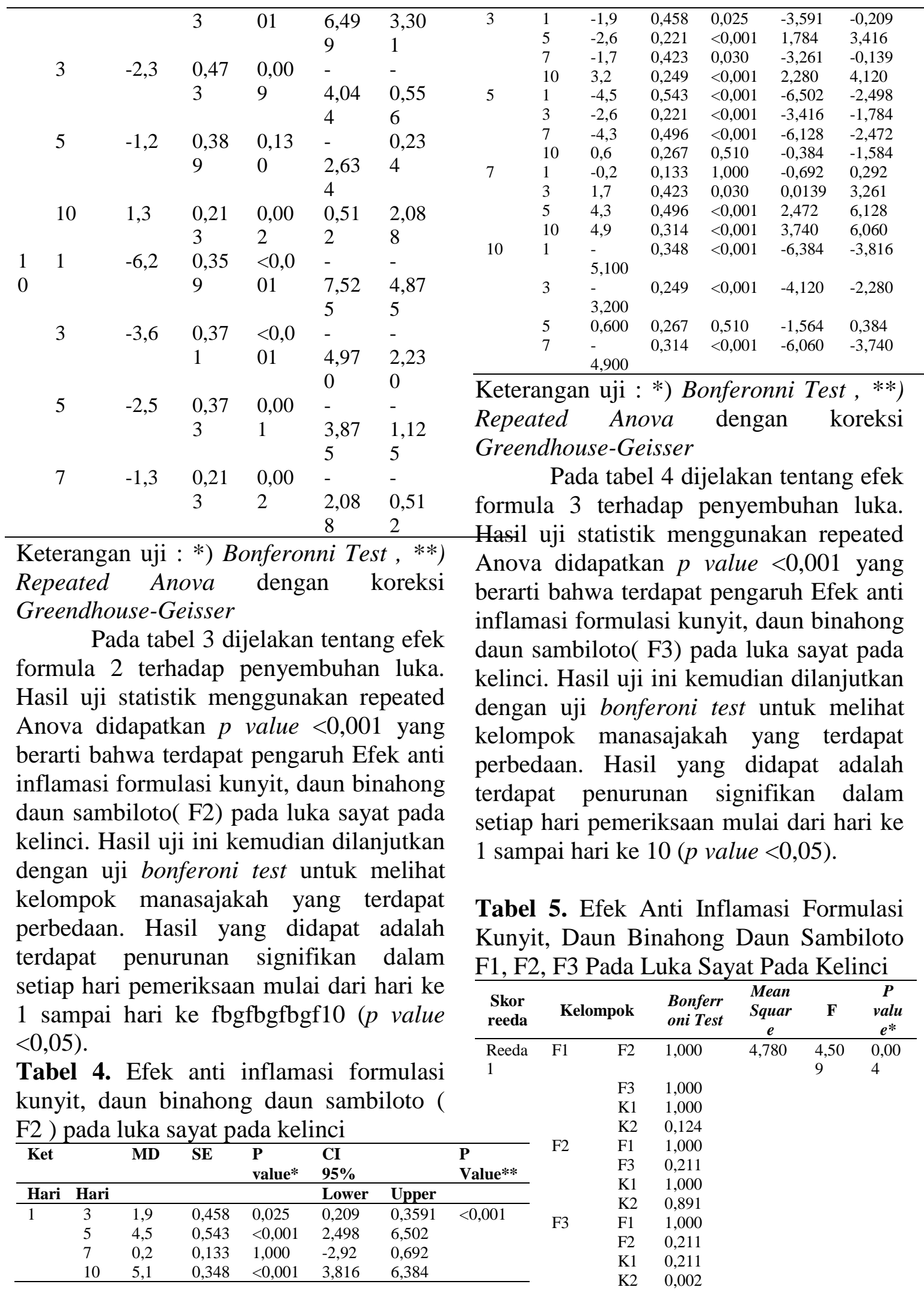




\begin{tabular}{|c|c|c|c|c|c|c|}
\hline & \multirow[t]{4}{*}{$\mathrm{K} 1$} & $\mathrm{~F} 1$ & 1,000 & & & \\
\hline & & $\mathrm{F} 2$ & 1,000 & & & \\
\hline & & F3 & 0,211 & & & \\
\hline & & $\mathrm{K} 2$ & 0,891 & & & \\
\hline & \multirow[t]{4}{*}{$\mathrm{K} 2$} & $\mathrm{~F} 1$ & 0,124 & & & \\
\hline & & $\mathrm{F} 2$ & 0,891 & & & \\
\hline & & F3 & 0,002 & & & \\
\hline & & $\mathrm{K} 1$ & 0,891 & & & \\
\hline \multirow{20}{*}{$\begin{array}{c}\text { Reeda } \\
3 \\
\end{array}$} & $\mathrm{~F} 1$ & $\mathrm{~F} 2$ & 1,000 & $\begin{array}{c}10,18 \\
0\end{array}$ & $\begin{array}{c}12,9 \\
77\end{array}$ & $<0,0$ \\
\hline & \multirow{6}{*}{ F2 } & F3 & 1,000 & & & \\
\hline & & K1 & 0,840 & & & \\
\hline & & K2 & 0,001 & & & \\
\hline & & $\mathrm{F} 1$ & 1,000 & & & \\
\hline & & F3 & 1,000 & & & \\
\hline & & K1 & 0,840 & & & \\
\hline & & K2 & $<0,001$ & & & \\
\hline & \multirow[t]{4}{*}{ F3 } & $\mathrm{F} 1$ & 1,000 & & & \\
\hline & & $\mathrm{F} 2$ & 1,000 & & & \\
\hline & & K1 & 0,080 & & & \\
\hline & & K2 & $<0,0001$ & & & \\
\hline & \multirow[t]{4}{*}{$\mathrm{K} 1$} & $\mathrm{~F} 1$ & 1,000 & & & \\
\hline & & $\mathrm{F} 2$ & 0,840 & & & \\
\hline & & F3 & 0,080 & & & \\
\hline & & K2 & 0,004 & & & \\
\hline & \multirow[t]{4}{*}{$\mathrm{K} 2$} & $\mathrm{~F} 1$ & $<0,001$ & & & \\
\hline & & $\mathrm{F} 2$ & $<0,001$ & & & \\
\hline & & F3 & $<0,001$ & & & \\
\hline & & $\mathrm{K} 1$ & 0,004 & & & \\
\hline \multirow{21}{*}{$\begin{array}{l}\text { Reeda } \\
5 \\
\end{array}$} & \multirow[t]{5}{*}{ F1 } & $\mathrm{F} 2$ & 1,000 & 41,33 & 34,0 & $<0,0$ \\
\hline & & & & & 63 & \\
\hline & & F3 & 0,067 & & & \\
\hline & & K1 & $<0,001$ & & & \\
\hline & & K2 & $<0,001$ & & & \\
\hline & F2 & $\mathrm{F} 1$ & 1,000 & & & \\
\hline & & F3 & 0,004 & & & \\
\hline & & K1 & 0,007 & & & \\
\hline & & K2 & $<0,001$ & & & \\
\hline & F3 & $\mathrm{F} 1$ & 0,067 & & & \\
\hline & & $\mathrm{F} 2$ & 0,004 & & & \\
\hline & & K1 & $<0,001$ & & & \\
\hline & & K2 & $<0,001$ & & & \\
\hline & K1 & $\mathrm{F} 1$ & $<0,001$ & & & \\
\hline & & $\mathrm{F} 2$ & 0,007 & & & \\
\hline & & F3 & $<0,001$ & & & \\
\hline & & K2 & 0,039 & & & \\
\hline & K2 & $\mathrm{F} 1$ & $<0,001$ & & & \\
\hline & & $\mathrm{F} 2$ & $<0,001$ & & & \\
\hline & & F3 & $<0,001$ & & & \\
\hline & & $\mathrm{K} 1$ & 0,039 & & & \\
\hline Reeda & F1 & $\mathrm{F} 2$ & 1,000 & 35,12 & 31,2 & $<0,0$ \\
\hline & & & & & 95 & 01 \\
\hline & & F3 & $<0,001$ & & & \\
\hline & & K1 & 0,149 & & & \\
\hline & & K2 & 0,000 & & & \\
\hline & $\mathrm{F} 2$ & $\mathrm{~F} 1$ & 1,000 & & & \\
\hline & & F3 & $<0,001$ & & & \\
\hline & & K1 & 0,149 & & & \\
\hline & & K2 & $<0,001$ & & & \\
\hline & F3 & $\mathrm{F} 1$ & $<0,001$ & & & \\
\hline & & $\mathrm{F} 2$ & $<0,001$ & & & \\
\hline & & K1 & $<0,001$ & & & \\
\hline & & K2 & 1,000 & & & \\
\hline & K1 & $\mathrm{F} 1$ & 0,149 & & & \\
\hline & & $\mathrm{F} 2$ & 0,149 & & & \\
\hline & & F3 & $<0,001$ & & & \\
\hline
\end{tabular}

\begin{tabular}{|c|c|c|c|c|c|c|}
\hline & K2 & $\begin{array}{l}\text { K2 } \\
\text { F1 } \\
\text { F2 } \\
\text { F3 } \\
\text { K1 }\end{array}$ & $\begin{array}{l}<0,001 \\
<0,001 \\
<0,001 \\
1,000 \\
<0,001\end{array}$ & & & \\
\hline $\begin{array}{c}\text { Reeda } \\
10 \\
\end{array}$ & F1 & $\mathrm{F} 2$ & 1,000 & $\begin{array}{c}14,78 \\
0 \\
\end{array}$ & $\begin{array}{c}21,8 \\
07 \\
\end{array}$ & $\begin{array}{l}<<0,0 \\
01\end{array}$ \\
\hline & & $\begin{array}{l}\text { F3 } \\
\text { K1 }\end{array}$ & $\begin{array}{l}1,000 \\
0,185\end{array}$ & & & \\
\hline & F2 & $\begin{array}{l}\text { K2 } \\
\text { F1 }\end{array}$ & $\begin{array}{l}0,000 \\
1,000\end{array}$ & & & \\
\hline & & F3 & 1,000 & & & \\
\hline & & $\begin{array}{l}\text { K1 } \\
\text { K2 }\end{array}$ & $\begin{array}{l}0,185 \\
<0,001\end{array}$ & & & \\
\hline & F3 & F1 & 1,000 & & & \\
\hline & & $\mathrm{F} 2$ & 1,000 & & & \\
\hline & & $\mathrm{K} 1$ & 0,185 & & & \\
\hline & & $\mathrm{K} 2$ & $<0,001$ & & & \\
\hline & $\mathrm{K} 1$ & $\mathrm{~F} 1$ & 0,185 & & & \\
\hline & & $\mathrm{F} 2$ & 0,185 & & & \\
\hline & & F3 & 0,185 & & & \\
\hline & & K2 & $<0,001$ & & & \\
\hline & $\mathrm{K} 2$ & $\mathrm{~F} 1$ & $<0,001$ & & & \\
\hline & & $\mathrm{F} 2$ & $<0,001$ & & & \\
\hline & & F3 & $<0,001$ & & & \\
\hline & & $\mathrm{K} 1$ & $<0,001$ & & & \\
\hline
\end{tabular}

Keterangan uji : *) one way anova

Berdasarkan tabel 5 didapatkan nilai REEDA pada hari pertama, hasil uji Anova menunjukkan perbedaan bermakna $\rho=0,004$, namun demikian saat dilakukan uji bonferroni tidak ada perbedaan bermakna pada setiap formula $(\rho>0,05)$. Pada nilai REEDA pada hari ketiga, hasil uji Anova menunjukkan perbedaan bermakna $\rho=<0,001$, saat dilakukan uji bonferroni tidak ada perbedaan bermakna pada formula 1,2,3 dan Kontrol 1 $(\rho>0,05)$, namun terdapat perbedaan bermakna pada kontrol $2(\rho<0,05)$. Pada nilai REEDA pada hari kelima, hasil uji Anova menunjukkan perbedaan bermakna $\rho=<0,001$, saat dilakukan uji bonferroni terdapat hampir seluruh formula terdapat perbedaan bermakna pada kontrol 2 $(\rho<0,05)$. Pada nilai REEDA pada hari ketujuh, hasil uji Anova menunjukkan perbedaan bermakna $\rho=<0,001$, saat dilakukan uji bonferroni terdapat perbedaan yang bervariasi pada setiap kelompoknya. Pada nilai REEDA pada hari kesepuluh, hasil uji Anova menunjukkan perbedaan bermakna 
$\rho=<0,001$, saat dilakukan uji bonferroni tidak ada perbedaan bermakna pada formula $1,2,3$ dan Kontrol $1 \quad(\rho>0,05)$, namun terdapat perbedaan bermakna pada kontrol $2 \quad(\rho<0,05)$. Berdasarkan hal tersebut menunjukkan bahwa baik formula 1 , 2 dan 3 paling efektif dalam menyembuhkan luka dan menunjukkan efektivitas yang sama, sedangkan pada kelompok K1 yang diberikan iodine lebih baik bila dibandingkan dengan $\mathrm{K} 2$ yang tidak diberikan intervensi apapun.

Tabel 6. Pengaruh anti inflamasi formulasi kunyit, daun binahong daun sambiloto terhadap kadar leukosit pada luka sayat kelinci

\begin{tabular}{|c|c|c|c|c|c|c|c|}
\hline $\begin{array}{l}\text { Skor } \\
\text { reeda }\end{array}$ & Kelompok & $\begin{array}{l}\text { Bonferr } \\
\text { oni Test }\end{array}$ & Mean & $\begin{array}{l}\text { Mean } \\
\text { Square }\end{array}$ & $\mathrm{F}$ & & $\begin{array}{l}\mathrm{P} \\
\text { value* }\end{array}$ \\
\hline \multicolumn{2}{|c|}{ Leukosit hari ke 1} & & & $10 \times 10^{6}$ & \multicolumn{2}{|c|}{1,067} & 0,384 \\
\hline & F1 & & $72 \times 10^{2}$ & & & & \\
\hline & $\mathrm{F} 2$ & & $73 \times 10^{2}$ & & & & \\
\hline & F3 & & $75 \times 10^{2}$ & & & & \\
\hline & K1 & & $74 \times 10^{2}$ & & & & \\
\hline & $\mathrm{K} 2$ & & $14 \times 10^{2}$ & & & & \\
\hline \multicolumn{8}{|c|}{ Leukosit hari ke 10} \\
\hline \multirow[t]{5}{*}{ F1 } & F1 & & $53 \times 10^{2}$ & $16 \times 10^{6}$ & 12,6 & & $<0,001$ \\
\hline & F2 & 1,000 & $49 \times 10^{2}$ & & & & \\
\hline & F3 & 1,000 & $54 \times 10^{2}$ & & & & \\
\hline & K1 & 1,000 & $57 \times 10^{2}$ & & & & \\
\hline & $\mathrm{K} 2$ & $<0,001$ & $81 \times 10^{2}$ & & & & \\
\hline \multirow[t]{4}{*}{ F2 } & F1 & 1,000 & & & & & \\
\hline & F3 & 1,000 & & & & & \\
\hline & K1 & 1,000 & & & & & \\
\hline & K2 & $<0,001$ & & & & & \\
\hline \multirow[t]{4}{*}{ F3 } & F1 & 1,000 & & & & & \\
\hline & $\mathrm{F} 2$ & 1,000 & & & & & \\
\hline & K1 & 1,000 & & & & & \\
\hline & K2 & $<0,001$ & & & & & \\
\hline \multirow[t]{4}{*}{ K1 } & F1 & 1,000 & & & & & \\
\hline & $\mathrm{F} 2$ & 1,000 & & & & & \\
\hline & F3 & 1,000 & & & & & \\
\hline & K2 & $<0,001$ & & & & & \\
\hline \multirow[t]{4}{*}{$\mathrm{K} 2$} & F1 & $<0,001$ & & & & & \\
\hline & F2 & $<0,001$ & & & & & \\
\hline & F3 & $<0,001$ & & & & & \\
\hline & K1 & $<0,001$ & & & & & \\
\hline \multicolumn{2}{|c|}{ Delta Leukosit } & & & & $10^{6}$ & 0,418 & 0,79 \\
\hline
\end{tabular}

Keterangan uji : *) one way anova

Berdasarkan tabel 6 didapatkan jumlah leukosit pada hari pertama, hasil uji Anova menunjukkan tidak ada perbedaan bermakna $\rho=0,384$, sehingga tidak dilakukan analisis lagi formula yang berbeda melalui uji Bonferroni Test. Pada jumlah leukosit pada hari kesepuluh, hasil uji Anova menunjukkan ada perbedaan bermakna $\quad \rho=<0,001, \quad$ selanjutnya dilakukan uji Bonferroni Test dan menunjukkan perbedaan yang bermakna pada kadar leukosit kelompok kontrol 2 yang lebih tinggi bila dibandingkan dengan F1,F2,F3 dan K1. Berdasarkan hal tersebut menunjukkan bahwa luka yang mendapatkan intervensi pengobatan akan lebih normal kadar leukositnya bila dibandingkan dengan luka yang tidak mendapat pengobatan.

\section{PEMBAHASAN}

Laserasi perineum merupakan robekan yang terjadi pada perineum karena kala II persalinan. Lebih dari $85 \%$ persalinan pervaginam akan mengalami trauma perineum, dan hampir 69\% memerlukan penjahitan (Miles, 2009). Angka kejadiannya berbeda-beda, tergantung pada praktik individu dan episiotomi yang bertujuan memperbesar vaginal outlet dan membantu fasilitas kesehatan yang ada.Empat puluh empat persen laserasi perineum terjadi karena persalinan spontan maupun buatan.Saat ini obat obat secara medis banyak di berikan untuk. mengembalikan keadaan luka perenium agar kembali normal. Budaya dari suku jawa dalam pemanfaatan tanaman di sekitar rumah sudah terjadi sejak jaman nenek moyang namun baru sedikit di buktikan secara ilmiah didiantaranya kunyit, daun binahong serta daun sambiloto yang sebenarnya mempunyai kandungan antiinflamasi dan sebagai antiseptik.

Sebelumnya penelitian terkait jamu hanya menggunakan satu formula saja. Hal ini yang menginspirasi peneliti untuk membuat campuran formula dari 
ketiga bahan Kunyit (curcuma longa), Daun Binahong (Anredera cordifolia) dan Daun Sambiloto (Andrographis paniculata) dalam menyembuhkan luka. Formula yang digunakan dalam pengobatan luka ini adalah dalam bentuk sediaan salep yang mudah untuk dioles dan diberikan pada luka yang dikemas dalam nama "Ramuan KUBISA". Hasil yang didapat diantaranya sebagai berikut:

Pada penelitian ini di tabel 4.1 dijelaskan nilai rata-rata skor REEDA pada formula 1, formula 2 formula 3 , Kontrol 1 dan kontrol 2. Hasil yang didapat skor REEDA pada akhir penelitian formula 1 , formula 2 formula 3 menunjukkan kesembuhan total sedangkan kontrol 1 masih ada yang belum sembuh $(0,9)$ dan juga pada kelompok kontrol 2 yang masih banyak menunjukkan skor REEDA 2,8 pada hari ke sepuluh.

Berdasarkan kedalaman luka maka luka dapat diklasifikasikan menjadi superficial yakni hanya mengenai epidermis saja, partial thickness yakni mengenai epidermis dan sebagian dermis, atau full thickness yakni luka menembus kulit melampaui dermis dapat mencapai jaringan subkutan, otot bahkan tulang (Judd, 2003: 34)

Secara singkat, proses penyembuhan luka dibagi dalam 3 fase.Fase pertama yaitu fase inflamasi atau fase inisial (lag phase) yang berlangsung pada saat terjadinya luka sampai hari ke-5.Pada fase ini terjadi perdarahan, kemudian pembekuan /penghentian perdarahan akibat kontraksi otot polos dinding pembuluh darah yang terluka dan penggumpalan darah oleh trombin dan fibrin.Ikut keluar bahan pertahanan tubuh berupa sel-sel leukosit dan antibodi. Disini terjadi vasodilatasi pembuluh darah, oedema.(Dr. Bisono. 2002: 15)

Pada penelitian ini fase penyembuhan luka dilakukan sampai hari ke sepuluh yang merupakan fase kedua dalam penyembuhan luka. Fase kedua yaitu fase fibroplasi atau fase proliferasi, berlangsung dari hari ke-6 sampai akhir minggu ke-3.Terjadi proliferasi sel-sel fibroblast yang berasal dari sel-sel mesensim yang belum berdiferensiasi. Terjadi pembentukan jaringan granulasi yang terdiri dari sel-sel fibroblast, serat kolagen yang dihasilkan oleh sel fibroblast, deposit sel-sel radang, kapiler baru, hasil angiogenesis. Terjadi penciutan luka akibat kontraksi serat-serat kolagen yang mempertautkan tepi luka. Terjadi epitelisasi akibat proses migrasi dan proses mitosis sel-sel stratum basal dan keratinosit lain yang terpapar luka (sel-sel kelenjar sebaseus, kelenjar keringat, dan akar rambut) ke tengah luka. Semua proses ini akan berhenti bila seluruh permukaan luka sudah tertutup epitel. Orang awam mengatakan luka sudah sembuh/sudah kering. Sebaliknya, proses akan berjalan terus bila permukaan luka belum tertutup epitel.

Gel Kubisa Di buat menjadi 3 formula dengan kombinasi zat aktifnya: Pada Formula 1 kandungan ekstrak binahong $40 \%$, ekstrak kunyit 3\%, ekstrak sambiloto $10 \%$ dan Basis Gel 46\%. : Pada Formula 1 kandungan ekstrak binahong $45 \%$, ekstrak kunyit 4\%, ekstrak sambiloto $12 \%$ dan Basis Gel 38\%. : Pada Formula 3 kandungan ekstrak binahong $50 \%$, ekstrak kunyit 5\%, ekstrak sambiloto $14 \%$ dan Basis Gel 30\%.

Pada penelitian ini di tabel 2 dijelakan tentang efek formula 1 terhadap penyembuhan luka Hasil yang didapat adalah terdapat penurunan signifikan 
dalam setiap hari pemeriksaan mulai dari hari ke 1 sampai hari ke 10 ( $p$ value $<0,05)$. Hal yang sama juga di tabel di tabel 4.3 dijelakan tentang efek formula 2 , dan di tabel 4.4 dijelakan tentang efek formula 3. Hal ini menunjukkan pada ketiga formula memberikan efek penyembuhan yang sama.

Pada penelitian ini tabel 5 menunjukkan efek formula 1 , formula, 2 , formula 3, kontrol 1 dan kontrol 2 pada setiap hari pemeriksaan. Berdasarkan hal diatas menunjukkan pada setiap hari pemeriksaan $(1,3,5,7,10)$ menunjukkan efek yang sama pada formula 1, formula, 2 , formula 3. Sedangkan pada kelompok kontrol 1 penyembuhan lebih baik dibandingkan kontrol 2.

Pada tabel 4.6 menunjukkan gejala perubahan leukosit. Pada hari pertama tidak ada perbedaan leukosit, namun pada hari ke sepuluh kelinci yang mendapatkan terapi formula 1,2 dan 3 menunjukkan jumlah leukosit yang lebih normal bila dibandingkan kelompok kontrol.

Senyawa sesquiterpen dalam minyak atsiri Senyawa sesquiterpen dalam minyak atsiri kunyit merupakan turunan dari senyawa terpen seperti alkohol yang bersifat bakterisida dengan merusak struktur tersier protein bakteri atau denaturasi protein (Tarwiyah, 2001). Sedangkan kurkumin adalah suatu senyawa fenolik. Turunan fenol ini akan berinteraksi dengan dinding sel bakteri, selanjutnya terabsorbsi dan penetrasi ke dalam sel bakteri, sehingga menyebabkan presipitasi dan denaturasi protein, akibatnya akan melisiskan membran sel bakteri. sedangkan aktivitas antibakteri curcumin dengan cara menghambat proliferasi sel bakteri.

Kunyit (Curcuma domestica Val.) meningkatkan kapasitas antioksidan tubuh secara drastis. Kerusakan oksidatif diyakini menjadi salah satu mekanisme dibalik penuaan dan sejumlah penyakit. Kerusakan oksidatif melibatkan radikal bebas, molekul yang sangat reaktif disertai dengan electron yang tidak memiliki pasangan. Radikal bebas cenderung bereaksi dengan zat organik yang penting, seperti protein asam lemak atau DNA. Alasan utama mengapa antioksidan sangat penting adalah karena mereka melindungi tubuh kita dari radikal bebas. Kurkumin ternyata memiliki kandungan antioksidan yang diperoleh dari struktur kimiawi yang dapat menetralisir radikal bebas. Namun kurkumin juga meningkatkan aktivitas enzim antioksidan tubuh. Dengan cara tersebut, kurkumin mampu melawan radikal bebas. Kurkumin memblokir radikal bebas secara langsung, kemudian menstimulasi mekanisme antioksidan tubuh.

Percobaan pada tikus yang disuntik dengan bahan ekstrak dari binahong dapat meningkatkan daya tahan tubuh, peningkatan agresivitas tikus dan tidak mudah sakit. Beberapa Beberapa penyakit yang dapat disembuhkan dengan menggunakan tanaman ini adalah: kerusakan ginjal, diabetes, pembengkakan jantung, muntah darah, tifus, stroke wasir, rhematik, pemulihan pasca operasi, pemulihan pasca melahirkan, menyembuhkan segala luka dalam dan khitanan, radang usus, melancarkan dan menormalkan peredaran dan tekanan darah, sembelit, sesak napas, sariawan berat, pusing-pusing, sakit perut, menurunkan panas tinggi, menyuburkan kandungan, maag, asam urat, keputihan, pembengkakan hati, meningkatkan vitalitas dan daya tahan tubuh (Manoi, 2009). 
Ekstrak metanol daun binahong dapat menurunkan kadar glukosa darah (Sukandar, 2011., Makalalag, 2013). Salep ekstrak daun binahong memiliki efektivitas pada penyembuhan luka yang terinfeksi bakteri Staphilococcus aureus(Paju, 2013).Hasil uji fitokimia ekstrak daun binahong ditemukan senyawa polifenol,alkaloid dan flavonoid. Pada konsentrasi $25 \%$ dapat menghambat pertumbuhan bakteri Staphylococcus aureus, pada konsentrasi $50 \%$ dapat menghambat pertumbuhanbakteri Pseudomonas aeruginosa (Khunaifi, 2010), juga dapat menghambat pertumbuhanbakteri Shigella flexneri (Ainurrochmah dkk, 2013). Daun binahong mengandungflavonoid yang menunjukkan aktivitas antioksidan. Ekstrak etil asetat daun binahongmempunyai aktivitas rendah sebagai antioksidan dengan nilai IC50 sebesar 1458,8 ppm(Rahmawati dkk, 2012). Binahong mempunyai aktivitas biologis karena adanyasenyawa bioaktif asam fenolat yang memiliki aktivitas antioksidan (Ekaviantiwi dkk,2013)

Kumala (2010), dalam identifikasi polifenol pada ekstrak daun binahong,terdapat satu golongan polimer fenol alam melanin tumbuhan yaitu senyawapirogalol dan sumber glikosida polifenol dari spesies Protea eximia.f. Murdiyanto dkk (2012) dalam identifikasi senyawa golongan triterpenoid ekstrakdaun binahong, menemukan senyawa 2,3,19,23-tetrahidroksi-12-ene24,28dimetil ester yang berfungsi sebagai anti bakteri

Menurut penelitian Fajriansyah tahun 2016 menyatakan bahwa salep ekstrak binahong $40 \%$ dapat menghasilkan kepadatan kolagen paling tinggi dibanding pemberian secara suspense oral ekstrak binahong dosis $100 \mathrm{mg} / \mathrm{kg} \mathrm{BB} / \mathrm{hari}$, pemberian kombinasi topical ekstrak binahong $40 \%$ da nsuspensi oral $100 \mathrm{mg} / \mathrm{kg} \quad \mathrm{BB} / \mathrm{hari}$, pemberian silver sulfadiazine, dan pemberian basis salep saja.Pemberian salep dilakukan 2x sehari, dan pengamatan dilakukan selama 5 hari, dan hari keenam pengamatan hasil dengan preparat

Berdasarkan dari hasil temuan diatas menunjukkan bahwa Anti inflamasi formulasi 1,2, dan 3 dari kunyit daun sambiloto dan daun binahong berpengaruh terhadap luka sayat pada kelinci. Pada Hipotesis 2 Ada perbedaan pengaruh efek formulasi anti inflamasi dari kunyit, daun binahong, dan sambiloto terhadap luka sayat pada kelinci dibandingkan pada kelompok kontrol.

\section{KESIMPULAN DAN SARAN}

\section{A. Kesimpulan}

1. Terdapat efek anti inflamasi formulasikunyit, daun binahong daun sambiloto( F1) pada luka sayat pada kelinci $(\rho<0,001)$.

2. Terdapat efek anti inflamasi formulasikunyit, daun binahong daun sambiloto( F2) pada luka sayat pada kelinci $(\rho<0,001)$.

3. Terdapat efek anti inflamasi formulasikunyit, daun binahong daun sambiloto( F3) pada luka sayat pada kelinci $(\rho<0,001)$.

4. Perbedaan efek anti inflamasi formulasi kunyit, daun binahong daun sambiloto F1, F2, F3 pada luka sayat pada kelinci $(\rho<0,05)$.

5. Terdapat pengaruh anti inflamasi formulasi kunyit, daun binahong daun sambiloto terhadap kadar leukosit pada luka sayat kelinci pada F1,F2,F3 
dibandingkan dengan kelompok kontrol $(\rho<0,001)$.

\section{B. Saran}

1. Disarankan untuk mengembangkan hasil penelitian dalam lingkup yang lebih luas serta dapat meningkatkan ranah penelitian dengan uji coba keamaan formula pada manusia

2. Disarankan hasil penelitian ini dapat dilanjutkan untuk melakukan kerjasama formula pada pabrikan yang lebih besar untuk dapat dikembangkan sampai pada lingkup produk formula yang berlisensi.

\section{DAFTAR RUJUKAN}

Ainurrochmah, A., Ratnasari, E. dan Lisdiana, L. 2013. Efektivitas Ekstrak Daun Binahong (Anredera cordifolia) Terhadap Penghambatan Pertumbuhan

Bakteri Shigella flexneridengan Metode Sumuran: Vol 2 No 3, 2013.

Surabaya.

Anief, M. 2005. ManajemenFarmasi. GadjahMada Press. Yogyakarta.

Bhat, S. V., B. A. Nagasampagi and S. Meenakshi. 2007. Natural Products :Chemistry and Application. Narosa Publishing House, New Delhi.India.

Bisono. 2002.Petunjuk Praktis Operasi Kecil.EGC. Jakarta.

Brown DL. 2004. Wound. In: Brown DL, Borschel GH, editors. Michigan Manual ofPlastic Surgery. 1st ed. Philadelphia, USA: Lippincott Williams \& Wilkins.
Clark, C. 1993. My First Book of Words and Pictures.London : Brown Watson.

Ekaviantiwi, TyasAyu., Fachriyah, Enny.,Kusrini, Dewi.2013.IdentifikasiAsamFenol atdariEkstrakEtanoldaunBinahong (Anrederacordifolia

(Ten.)Stennis)danUjiAktivitasAntio ksidan.Chem Info, Vol1, No1, Hal 283-293.

Hidayati, E., N. Juli, E. Marwani. 2002. Isolasi Enterobacteriaceae Patogen dari Makanan Berbumbu dan Tidak Berbumbu Kunyit (Curcuma longa L.)

Serta Uji Pengaruh Ekstrak Kunyit (Curcuma longa L.) Terhadap Pertumbuhan Bakteri Yang Diisolasi. FMIPA Universitas Nahdlatul

Wathan-Mataram. Bandung.

Judd, H. 2003. Wound care made incredibly easy. 1st ed. Philadelphia: Lippincott Williams \& Wilkins. Hal : 30-34.

Khunaifi, M. 2010. Uji aktivitas antibakteri ekstrak daun binahong (Anredera cordifolia (ten.) Steenis) terhadap bakteri Staphylococcus aureus dan Pseudomonas aeruginosa. Skripsi. Malang: UIN Malang.

Kumala, K.R. 2010. Identifikasi Polivenol pada Ekstrak Daun Binahong (Anredera cordifolia (tenore) stanis). (tesis). UNIMUS.

Makalalag, I.W., A. Wullur, dan W. Wiyana.2013. Uji ekstrak daun binahong (anrederacordifolia (ten.) steenis) terhadap kadargula darah pada tikus putih jantan galurwilstar(Rattus norvegius) 
yang diinduksisukrosa.Jurnal Ilmiah Farmasi-Unsrat 2(1) : 2834.

Manoi, F. 2009. Binahong (Anredera cordifolia)(Ten) Steenis Sebagai Obat. Jurnal Warta Penelitian Dan Pengembangan Tanaman Industri. Volume 15 Nomor 1:3.

Miles, Matthew B \& a. Michael Huberman. 2009. Analisis Data Kualitatif.Jakarta: UI-Press.

Paju, N. 2013. Uji Efektifitas Salep Ekstrak Daun Binahong (Anredera cordifolia)

pada Kelinci (Oryctolagus cuniculus) yang terinfeksi Staphylococcus

aureus. Jurnal Ilmiah Farmasi, Hal 23-24.

Rahmawati. (2009). Pengaruh stimulasi elektrikterhadap pengurangan luas luka padapenyembuhan luka (debth wound).Jurnal Pendidikan Mutiara Ilmu. 2009; 4(2): 102-107.

Retno Iswari Tranggono. 2007. Buku Pegangan Ilmu Pengetahuan Kosmetik. Jakarta : PT. Gramedia Pustaka Utama. Anggota IKAPI.

Rochani, N. 2009. Uji Aktivitas Anti jamur Ekstrak Daun Binahong (Anrederacordifolia (Tenore) Steen) terhadap Candida Albicans serta Skrining Fitokimianya. Skripsi Tidak Diterbitkan. Surakarta: FakultasFarmasi UMS Surakarta.

Said, Ahmad. 2007. Khasiat dan Manfaat Temulawak. Jakarta: Sinar Wadja Lestari.

Setiaji, A. 2009. Uji Aktivitas Antibakteri Ekstrak Petroleum Eter, Etil Asetat Dan Etanol 70\% Rhizoma Binahong (Anredera cordifolia (Tenore) Steenis) Terhadap
Staphylococcusaureus ATCC 25923 Dan Escherichia coli ATCC $11229 \quad$ Serta Skrining Fitokimianya. Skripsi Tidak Diterbitkan. Surakarta : Fakultas Farmasi UMS Surakarta.

Sukandar, E.Y., Elfahmi, Nurdewi. (2009). Pengaruh Pemberian Ekstrak Air Daun JatiBelanda (Guazuma Ulmifolia Laml.) terhadap Kadar LipidDarah pada TikusJantan. Jurnal Kesehatan Masyarakat, 8 (2):102-112.

Tarwiyah, K. 2001. Tapioka. Dewan Ilmu Pengetahuan, Teknologi dan Industri, Sumatera Barat.

Tshikalange T.E, JJM. Meyer and AA.Husein. (2005). Antimicrobial activity,

toxicity and the isolation of a bioactive compound from plants used to treatsexually transmitted diseases, Di dalam: Astuti, S.M., Mimi S.A.M., danRetno A. B.M., Determination of Saponin Compound From Anredera Cordifolia (Ten) Steenis Plant (Binahong) To Potential Treatment For Several Diseases, Journal of Agricultural Science, Vol.3 No.4. 